\title{
COEZEFSPONNEINCE.
}

ARBUSCOLITES ARGENTEA, MURRAY.

SrR,-Though unable to refer to Murray's description of this fossil, the quotations given from it by Mr. R. Etheridge, jun., in the June Number of the Magazine, p. 269 , recalled at once to my mind the characters of a somewhat similar fossil I discovered some years since in rocks of Lower Carboniferous age at Arsaig in Nova Scotia. On the shore at this place, near McAras Brook, there are exposed beds of a dark, Oolitic limestone, which, in places, are interpenetrated in all directions with bright glistening threads " resembling' broken bits of silver-wire." These occur in curved fragments of about two or three lines in length and about one-tenth of a Jine in thickness; they are solid, and, so far as I can see, neither grooved nor branched, and in these respects they differ from the forms described by Murray.

The only other fossils visible in the same beds are very poorly preserved casts of Producti; their presence supports the opinion expressed by $\mathrm{Mr}$. Etheridge that these glistening threads are merely the long spines of this Brachiopod; but if this is the case, it is very peculiar that, whilst the shells of the Producti have to a large extent disappeared, their spines should have been preserved in such great numbers and such perfect condition. On this supposition too, it is remarkable that similar spines (?) should not have been noticed in limestones in which Producti abound, for in the beds mentioned they are very conspicuous objects. Inclosed are two small pieces of the rock, showing these spines(?). On one is what appears to be the expanded base of attachment. Geo. Jennings Hinde.

Toronto, June, 21 st, 1878.

\section{AGE OF THE ROCKS OF MONTE GENEROSO.}

Srr,-I have several times had the pleasure of ascending Monte Generoso, a mountain easy of access, which lies between the Lakes of Como and Lugano, and from which one of the finest views on the continent is obtainable. After winding up through chestnut woods from Mendisio for some four miles, the pathway ascends a somewhat steep incline in zigzags. The rocks here are remarkably white and dazzling and might be almost mistaken for chalk. For some $40 \mathrm{ft}$. or more below, they are coloured red, similar to the Red Chalk in Yorkshire.

On the last occasion of my visit, I met with a French geologist at M. Paston's Hotel near the summit, and from him I obtained some information about these rocks which had excited my curinsity, but not enough to satisfy me as to their position relative to English strata. He classed them as follows:-

\section{JURA LOMBARD.}

\section{Majolique \\ Calcaire rouge \\ Calcaire grès \\ Calcaire noir}

Conglomerat Marnewx 
Can you, or can any of your readers give me some more information on this subject?

Edw. Maule Colh.

Wetwang Vioarage, York.

P.S.-Can you recommend to me any notices on "Red Chalk" in England?-E. M. C.

The Rev. E. M. Cole will obtain the information he seeks, by consulting the following papers, which are picked out of a list still in course of formation.

Blake, Rev. J. F.-Proceed. Geol. Assoc. vol. v. p. 232, etc.

Judd, J. W.-Quart. Journ. Geol. Soc. vol. xxiii. p. 227.

Phillips, Prof. J. Geol. of Yorkshire, 3rd edit. p. 75.

Seeley, Prof. H. G._Ann. and Mag. of Nat. Hist. 3rd series, vol. vii. p. 233, 1861 ; Quart. Journ. Geol. Soc. vol. xx. p. 327.

Taylor, Richard.-Phil. Mag. 1823, vol. 61, p. 81.

Wiltshire, Rev. T.-Quart. Journ. Geol. Soc. vol. xxv. p. 185.

For Analysis of Red Chalk see-

Church, A. H.-Chemical News, vol. 31, p. 199; or GgoL. MAG. Vol. II. p. 331.

B. B. W.

\section{OBITUARY.

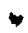 \\ THE REV. WILLIAM BRANWHITE CLARKE, \\ M.A., F.R.S., F.R.G.S., F.G.S., ETC. \\ Born 2 June, 1798. Died 17 June, 1878.}

We regret to record the death of another veteran geologist, the "Father of Australian Geology," the Rev. W. B. Clarke, which took place at his residence near Sydney, in the eighty-first year of his age. Mr. Clarke was born at East Bergholt, Suffolk, on the 2nd June, 1798, and was partly educated at Dedham Grammar School. He entered Cambridge in 1817, becoming a member of Jesus College, took his B.A. in January, 1821, and became M.A. and Member of Senate in 1824.

From 1821 to 1824 be acted in his clerical capacity at Ramsholt and other places, and during this period made fifteen distinct geological and other excursions on the Continent, in addition to those prosecuted by him in this country. During the years 1830-31 Mr. Clarke was present at many of the scenes of the Belgian War of Independence, and the last siege of Antwerp. His clerical duties were continued up to the year 1839, when he left for New South Wales, with the object of examining the physical structure of the country, and regaining health lost during a severe illness. From the time of his arrival till 1844, Mr. Clarke was in clerical charge of the country from Paramatta to the Hawkesbury River, and for a portion of the time conducted the King's School. In that year he undertook the charge of Campbelltown, but in 1847 he became minister of Willoughby, which he held till 1870, then retiring, after nearly fifteen years' service in the church, with a testimonial from his parishioners, expressive of their sympathy and respect. 